\title{
Drilling and Construction Information for Well 8-0339-01, South Point Tank Exploratory Well, Island of Hawaii
}

By Charles J. Ewart

U.S. GEOLOGICAL SURVEY

Open-File Report 98-642

Prepared in cooperation with the

DEPARTMENT OF WATER SUPPLY

COUNTY OF HAWAII 


\section{U.S. DEPARTMENT OF THE INTERIOR \\ BRUCE BABBITT, Secretary}

U.S. GEOLOGICAL SURVEY

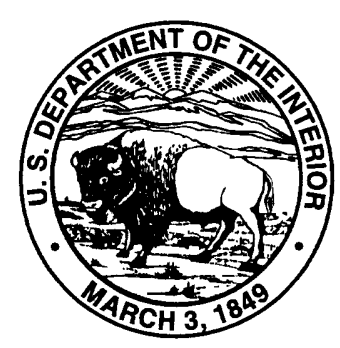

Charles G. Groat, Director

The use of firm, trade, and brand names in this report is for identification purposes only and does not constitute endorsement by the U.S. Geological Survey.

For additional information write to:

District Chief

U.S. Geological Survey

677 Ala Moana Blvd., Suite 415

Honolulu, HI 96813
Copies of this report can be purchased from:

U.S. Geological Survey

Branch of Information Services

Box 25286

Denver, CO 80225-0286 


\section{CONTENTS}

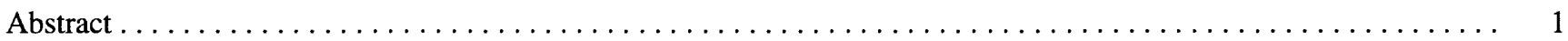

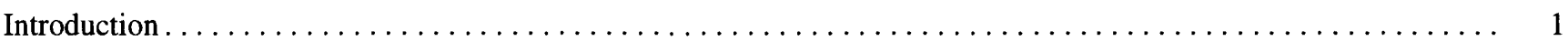

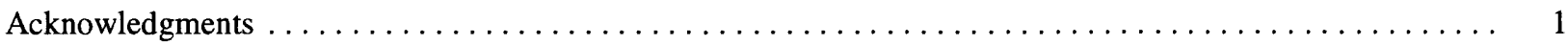

Setting . . . . . . . . . . . . . . . . . . . . . . . . . . . . . .

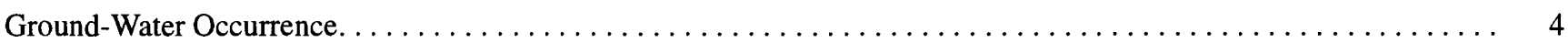

Drilling, Construction, and Drillers' Log for South Point Tank Exploratory Well (State Well Number 8-0339-01) . . . . 4

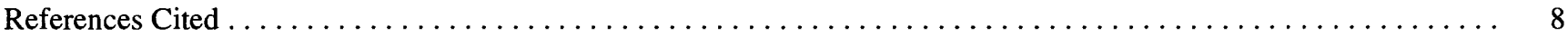

Figures

1-4. Maps showing

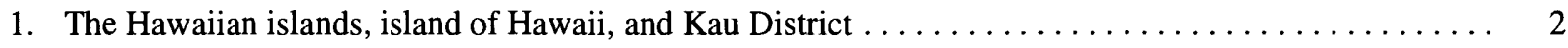

2. The South Point tank exploratory well (State well number 8-0339-01), island of Hawaii . . . . . . . 3

3. Generalized geology of the Kau District, island of Hawaii. $\ldots \ldots \ldots \ldots \ldots$

4. Selected wells, shafts, springs, and tunnels, Kau District, island of Hawaii . . . . . . . . . . 6

5. Diagram showing construction details of the South Point tank exploratory well (State well number 8-0339-01), island of Hawaii . . . . . . . . . . . . . . . . . . . . . . . .

\section{Tables}

1. Elevation, water-level, and chloride-concentration data for selected drilled wells in the Kau District,

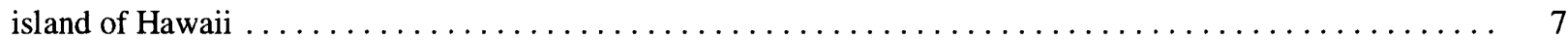

2. Construction data for South Point tank exploratory well, island of Hawaii $\ldots \ldots \ldots . \ldots$

3. Driller's log of South Point tank exploratory well (State well number 8-0339-01), island of Hawaii . . . . . . . . 10

4. Water-quality measurements for South Point tank exploratory well for water samples obtained by

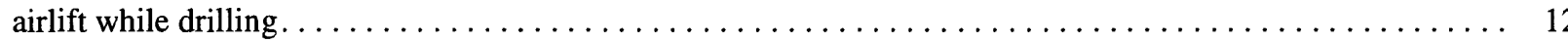

5. Depths to water during drilling at South Point tank exploratory well (State well number 8-0339-01),

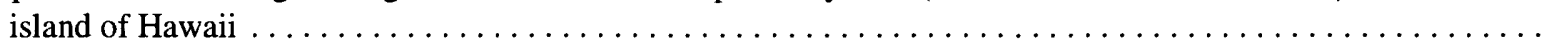

\section{Conversion Factors}

\begin{tabular}{rll}
\hline Multiply & By & To obtain \\
\hline foot (ft) & 0.3048 & meter \\
gallon (gal) & 3.785 & liter \\
million gallons per day (Mgal/d) & 0.04381 & cubic meter per second \\
mile (mi) & 1.609 & kilometer \\
inch (in.) & 25.4 & millimeter \\
\hline
\end{tabular}

Elevations in this report are referenced to mean sea level.

Specific conductance is given in microsiemens per centimeter $(\mu \mathrm{S} / \mathrm{cm})$ at $25^{\circ}$ Celsius. Microsiemens per centimeter is numerically equivalent to micromhos per centimeter.

Abbreviation used: $\mathrm{mg} / \mathrm{L}$, milligrams per liter. 


\title{
Drilling and Construction Information for Well 8-0339-01, South Point Tank Exploratory Well, Island of Hawaii
}

\author{
By Charles J. Ewart
}

\begin{abstract}
The South Point tank exploratory well (State well number 8-0339-01) was drilled at the Hawaii County Department of Water Supply tank located at the intersection of South Point Road and State Highway 11, at an elevation of 1,944 feet. The well was drilled into rocks of the Mauna Loa Volcano to a depth of 1,946 feet below ground surface and encountered a water table standing at an elevation of 435 feet. Well-construction data, a driller's $\log$, and a summary of ground-water occurrence are provided. The well is one of three exploratory wells drilled on the island of Hawaii between May 1997 and July 1998 in cooperation with the County of Hawaii Department of Water Supply.
\end{abstract}

\section{INTRODUCTION}

The South Point tank exploratory well was the first of three deep exploratory wells drilled on the island of Hawaii between May 1997 and February 1998. These wells were drilled by the U.S. Geological Survey (USGS) as part of a program of exploratory/monitor well drilling carried out in cooperation with the County of Kauai Department of Water, the County of Hawaii Department of Water Supply, and the City and County of Honolulu Board of Water Supply. The program, begun in 1993, is designed to provide hydrologic and geologic information for aquifers in each of the island counties. This information is vital to the understanding of the ground-water systems on each island and for the estimation of the amount of available ground water.

In addition to providing needed hydrogeologic information, the exploratory wells completed under this program will be used as long-term monitoring wells to provide data and information for the management, protection, and preservation of the ground-water resources. The rotation of the drilling rig between islands and the duration of drilling on each island are determined by the three county water managers. Drilling sites are selected and prioritized jointly by the county water departments and the USGS.

The purpose of the South Point tank exploratory well was to provide information on the little known ground-water resources of the western part of the Kau District (fig. 1), which is an area that often has water shortage during periods of low rainfall. The well was drilled on County of Hawaii property at the intersection of South Point Road and State Highway 11 at an elevation of $1,944 \mathrm{ft}$ (fig. 2). Water was encountered at a depth of $1,508 \mathrm{ft}$ below land surface (elevation $435 \mathrm{ft}$ ) and remained at that level for the duration of the drilling to final depth. The extent of this high-level water body and the nature of the impounding structures are not known. This report presents geohydrologic data, driller's log, and construction details of the well.

\section{Acknowledgments}

The USGS gratefully acknowledges the assistance of the Hawaii County Department of Water Supply in site preparation and logistical support throughout the period of well construction.

\section{Setting}

The South Point tank exploratory well (State well number 8-0339-01) is located at the Hawaii County Department of Water Supply storage tank at the intersection of South Point Road and State Highway 11 on the southern slope of Mauna Loa Volcano in the southwestern part of the Kau District (fig. 2). The Kau Dis- 


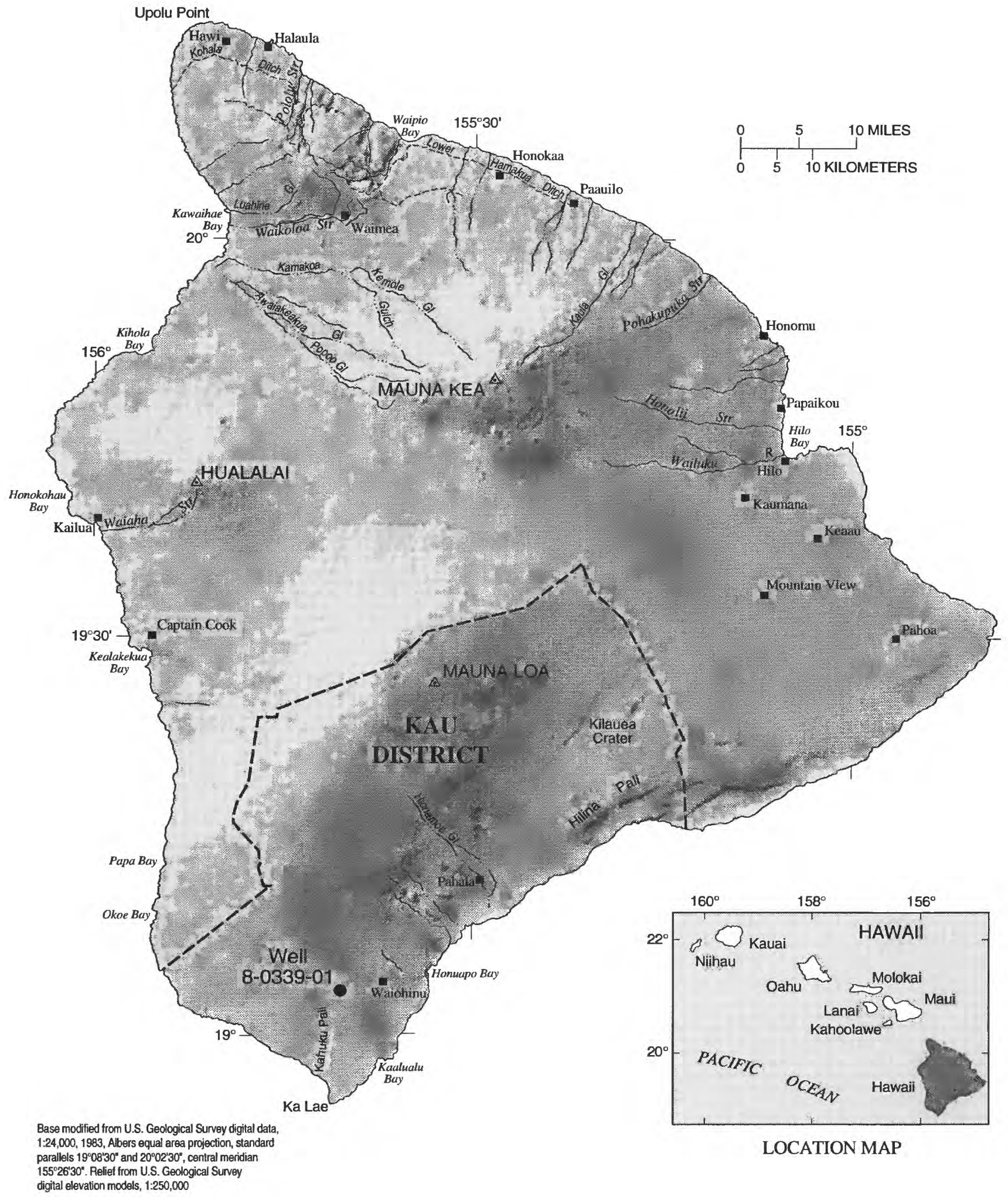

Figure 1. Location of Hawaiian islands, island of Hawaii, and Kau District. 


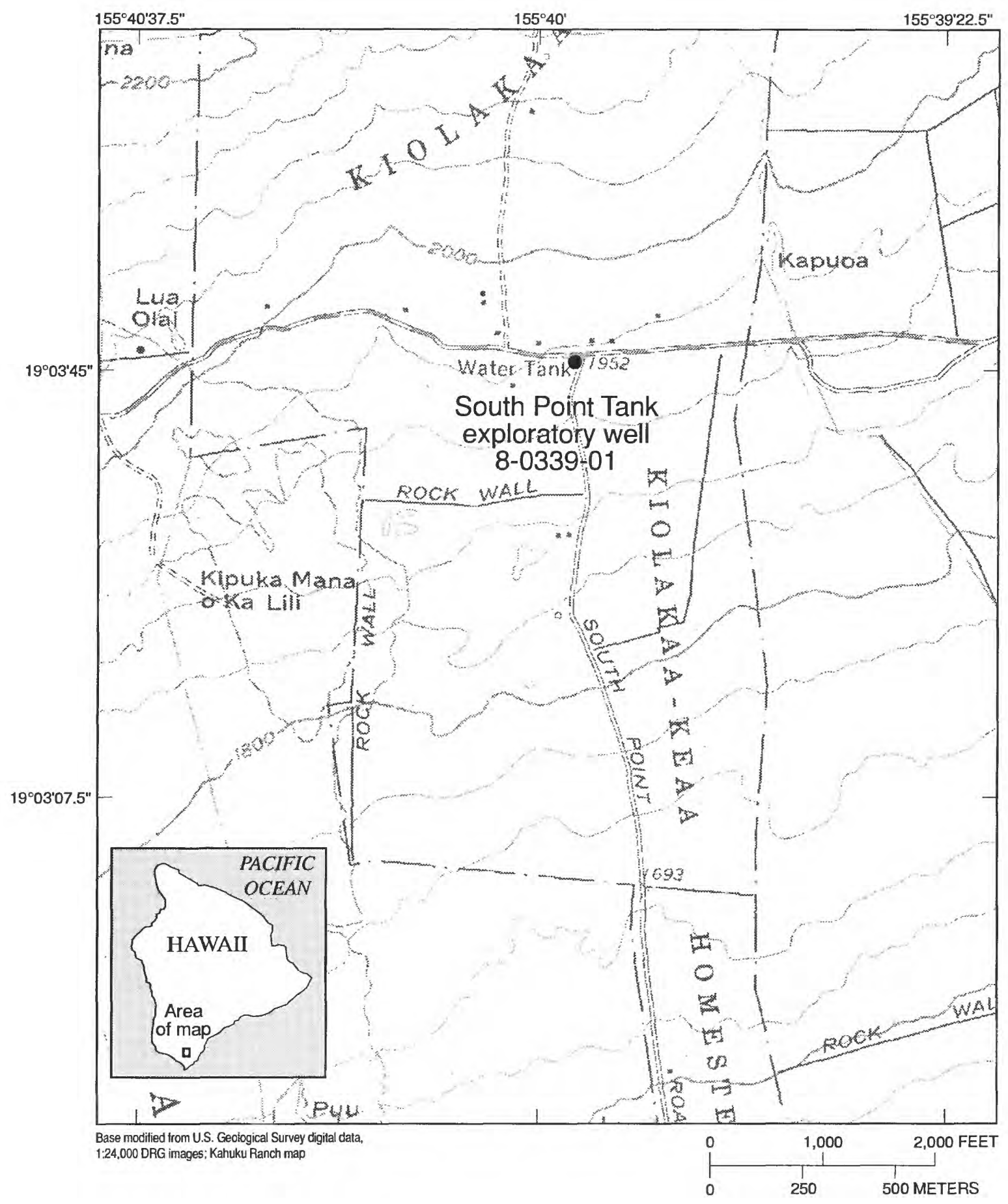

Figure 2. Location of the South Point Tank exploratory well (State well number 8-0339-01), island of Hawaii. 
trict is the largest of the island of Hawaii's nine districts and has a land area of almost 625,000 acres. Elevations within the District range from sea level to $13,700 \mathrm{ft}$ at the summit of Mauna Loa. Average annual rainfall within the District ranges from about 20 in. at the coast near South Point (Ka Lae) to more than $125 \mathrm{in}$. at the 3,000 ft elevation between Waiohinu and Pahala and about 100 in. at the summit of Kilauea Volcano.

The Kau District consists of rocks from Mauna Loa Volcano which include lava flows and pyroclastic deposits, and rocks from Kilauea Volcano which also formed by lava flows and pyroclastic deposits (fig. 3). The lavas of the Kau Basalt, which make up most of the District, are highly permeable (Stearns and Macdonald, 1946), and no streams within the Kau District reach the sea except after periods of intense rainfall (Davis and Yamanaga, 1966).

\section{GROUND-WATER OCCURRENCE}

The occurrence of ground water in the Kau District is described in detail by Stearns and Clark (1930), Stearns and Macdonald (1946), and Davis and Yamanaga (1966 and 1973). The following is a generalized summary from these works for that part of the District formed by rocks from Mauna Loa Volcano.

Within the Kau District, ground water is found as basal water, which is that roughly lens-shaped body of freshwater near sea level floating on seawater and as high-level ground water, which may be impounded by volcanic dikes or other structures or perched on lowpermeability geologic units such as volcanic ash. Recharge to the basal ground-water body is from direct infiltration of rainfall on the permeable land surface, from subsurface discharge of high-level ground-water bodies, and from infiltration of water flowing over permeable rock in stream channels. Recharge to the highlevel ground-water body is from direct infiltration of rainfall. Discharge from the basal water body is from springs and seeps visible at the coast or discharging below sea level offshore. Evidence of substantial ground-water flow at the coast is provided by the large discharge at Ninole and Kawaa Springs (fig. 4). Average discharge from these springs is estimated to range between 30 to $50 \mathrm{Mgal} / \mathrm{d}$.

Chloride-ion concentration is about $100 \mathrm{mg} / \mathrm{L}$ at Kawaa Springs and ranges between 300 to $400 \mathrm{mg} / \mathrm{L}$ at Ninole Springs (fig. 4). Along the coast southwestward from Honuapo to Ka Lae, the visible ground-water discharge decreases and the salinity of the water increases. A dug well near the shore of Waikapuna Bay yielded water with a chloride-ion concentration of about 2,000 $\mathrm{mg} / \mathrm{L}$, and at a dug well near Waipouli the chloride-ion concentration was about $1,800 \mathrm{mg} / \mathrm{L}$. Dug wells and a spring at Kaalualu yielded water with a chloride-ion concentration between 2,000 and 3,000 mg/L. Highlevel ground water is manifested by the occurrence of springs and seeps primarily between Pahala and Waiohinu at elevations between 2,000 and 5,000 ft. The springs are perched in lava flows by intercalated ash beds. The larger springs were developed by horizontal tunneling along the ash layers during the period 192130 to provide water for sugarcane fluming from upland fields to the sugar mill at Honuapo. The perched water bodies are irregular and discontinuous because of great variations in the permeability and in the thickness of the ash layers. The discharge from the development tunnels fluctuates with rainfall. Evidence of a high-level body of ground water was discovered in 1946 when a shaft (8-1128-01) designed to develop basal water encountered water at $228 \mathrm{ft}$ above sea level near Pahala. Subsequently the Hawaii County Department of Water Supply drilled an exploratory well (8-1229-01) near Pahala that encountered water standing $384 \mathrm{ft}$ above sea level. Elevations, water levels, and chloride concentrations for selected wells in the Kau District are shown in table 1.

Most recently, the South Point tank exploratory well encountered high-level ground water standing at an elevation of $435 \mathrm{ft}$. The extent of these high-level ground-water bodies and the nature of the impounding structures are not known.

\section{DRILLING, CONSTRUCTION, AND DRILLER'S LOG FOR SOUTH POINT TANK EXPLORATORY WELL (STATE WELL NUMBER 8-0339-01)}

The South Point tank exploratory well was drilled with an air-rotary system using a mixture of air, water, foam, and polymer as the drilling fluid to aid in stabilizing the borehole and to remove drill cuttings and water. Samples of the drill cuttings were obtained at frequent intervals except where drilling-fluid circulation was lost. Drilling began on May 7, 1997 and was completed on August 5, 1997. A 17-1/2 in. hole was drilled to a 


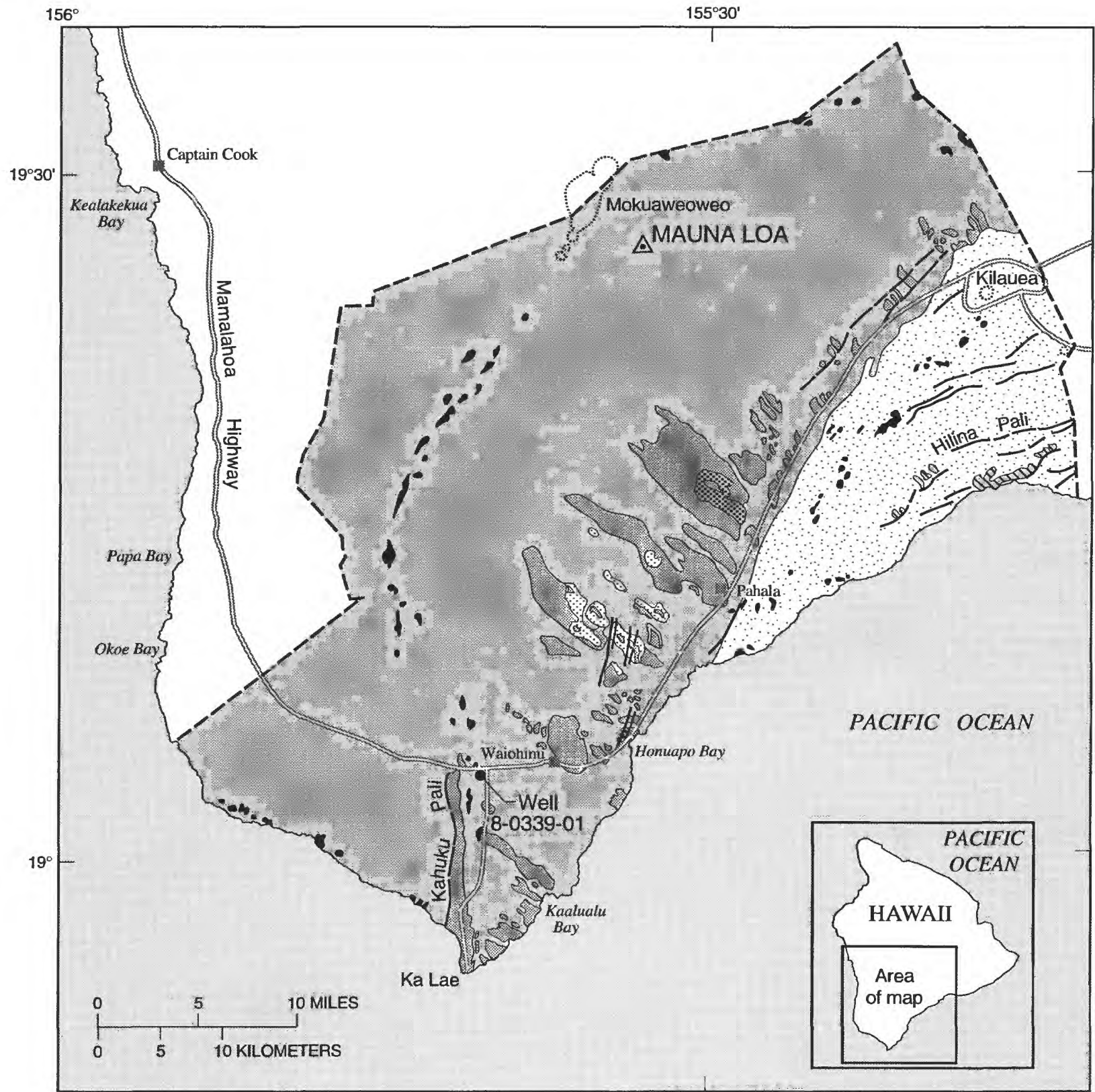

Base modified from U.S. Geological Survey digital data, $1: 24,000,1983$, Albers equal area projection, standard paraliels $19^{\circ} 08^{\prime} 30^{\circ}$ and $20^{\circ} 02^{\prime} 30^{\circ}$, central menidian

$155^{\circ} 26^{\prime} 30^{\prime \prime}$

\section{EXPLANATION}

MAUNA LOA VOLCANO

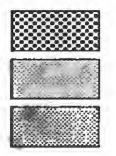

Mud flow of 1868 (recent)

Kau Basalt (Pleistocene)

Kahuku Basalt capped by

Pahala Ash (Pleistocene)

CINDER AND SPATTER CONES

$\longrightarrow$ FAULT

$155^{\circ} 30^{\circ}$ 




EXPLANATION

$\begin{array}{clcc}8-0339-01 & \text { DRILLED WELL AND NUMBER } & \downarrow & \text { WATER-DEVELOPMENT TUNNEL } \\ 0 & \text { DUG WELL OR WATER HOLE } & -2000- & \begin{array}{c}\text { TOPOGRAPHIC CONTOUR--Interval } \\ 1,000 \text { feet }\end{array} \\ 8-1128-01 & \text { SHAFT AND NUMBER } & \text { CRATER }\end{array}$

Figure 4. Selected wells, shafts, springs, and tunnels, Kau District, island of Hawaii. 
Table 1. Elevation, water-level, and chloride-concentration data for selected drilled wells in the Kau District, island of Hawaii

[Data from: State of Hawaii Commission on Water Resource Management records; Davis and Yamanaga, 1973; and U.S. Geological Survey, Hawaii District files. --, no data; $>$, greater than; $<$, less than]

\begin{tabular}{ccccc}
\hline State well no. & Year drilled & $\begin{array}{c}\text { Elevation } \\
\text { (feet) }\end{array}$ & $\begin{array}{c}\text { Water level } \\
\text { (feet) }\end{array}$ & $\begin{array}{c}\text { Chloride } \\
\text { concentration } \\
\text { (milligrams per liter) }\end{array}$ \\
\hline $8-0139-01$ & 1990 & 1,259 & 7.2 & 115 \\
$8-0246-01$ & 1982 & 1,049 & 9.5 & $>300$ \\
$8-0335-01$ & 1971 & 745 & 10 & 10 \\
$8-0339-01$ & 1997 & 1,944 & 435 & -- \\
$8-0437-01$ & 1994 & 1,300 & 1,016 & 5 \\
$8-0533-01$ & 1946 & 22 & -- & 1,220 \\
$8-0533-02$ & 1965 & 94 & 2 & 580 \\
$8-0533-03$ & 1965 & 89 & 3.2 & 500 \\
$8-0632-01$ & 1965 & 103 & 2.9 & 500 \\
$8-1128-01$ & 1947 & 774 & 228 & 12 \\
$8-1128-02$ & 1970 & 304 & 8.7 & 9 \\
$8-1129-01$ & 1974 & 672 & 14 & 55 \\
$8-1229-01$ & 1972 & 1,112 & 384 & 7 \\
$8-8540-01$ & 1941 & 51 & $<0.5$ & 650 \\
\hline
\end{tabular}


Table 2. Construction data for South Point tank exploratory well, island of Hawaii [Elevation datum is mean sea level; in., inch; $\mathrm{ft}$, feet; id, inside diameter]

\begin{tabular}{|c|c|}
\hline Well name & South Point tank exploratory well \\
\hline State well number . & 8-0339-01 \\
\hline Latitude and longitude & $19^{\circ} 03^{\prime} 45^{\prime \prime} 155^{\circ} 39^{\prime} 57^{\prime \prime}$ \\
\hline Hawaii tax map key number.... & $9-3-04: 24$ \\
\hline Landowner & Hawaii County Department of Water Supply \\
\hline Well completed . . . . . . & August 5, 1997 \\
\hline Driller ........... & G. Wayne Heick, USGS \\
\hline Surface hole diameter . & $17-1 / 2$ in. \\
\hline Bottom of surface casing & $1,444 \mathrm{ft}$ \\
\hline Surface casing type and diameter. . & Steel, 0.188-in. wall, 12 -in. id \\
\hline Final hole diameter . . . . . . . . . & $8-3 / 4$ in. \\
\hline Bottom of well elevation. ......... & $-2 \mathrm{ft}$ \\
\hline Inner casing type and diameter $\ldots \ldots \ldots \ldots \ldots \ldots \ldots \ldots \ldots \ldots \ldots$ & Steel, solid and slotted, 4-in. id \\
\hline Slotted interval elevations....... & $500 \mathrm{ft}$ to $-2 \mathrm{ft}$ \\
\hline Reference mark elevation (brass plate). & $1,943.75 \mathrm{ft}$ \\
\hline Measuring point (top of casing) elevation & $1,944.26 \mathrm{ft}$ \\
\hline Water level and date of measurement ..... & $436.1 \mathrm{ft}$, August 1, 1997 \\
\hline
\end{tabular}

depth of $503 \mathrm{ft}$ and $500 \mathrm{ft}$ of 12 -in. inside-diameter casing was grouted in place. The remainder of the hole was drilled with a 8-3/4 in. tricone tungsten carbide bit. Well-construction data are provided in table 2 and construction details are shown in figure 5 . The well was cased with 4-in. inside diameter, flush joint, blank and slotted steel casing. The 4.5 -in. outside-diameter casing was grouted to the 12 -in. casing from a depth of $30 \mathrm{ft}$ to the surface. Table 3 contains a driller's log of the well and table 4 presents some water-quality data on water that was air-lifted from the well. Depths to water during drilling are shown in table 5 .

\section{REFERENCES CITED}

Davis, D.A., and Yamanaga, George, 1966, Preliminary report on the water resources of the Kau District, Hawaii: Hawaii Division of Water and Land Development, Department of Land and Natural Resources, Circular C27, 25 p.
Davis, D.A., and Yamanaga, George, 1973, Water resources summary, island of Hawaii: Hawaii Division of Water and Land Development, Department of Land and Natural Resources, Report R47, 42 p.

Langenheim, V.A.M., and Clague, D.A., 1987, The Hawaiian-Emperor volcanic chain, chap. 1 of Decker, R.W., Wright, T.L., and Stauffer, P.H., eds., Volcanism in Hawaii: U.S. Geological Survey Professional Paper 1350 , v. 1, p. 55-84.

Stearns, H.T., and Clark, W.O., 1930, Geology and water resources of the Kau District, Hawaii: U.S. Geological Survey Water-Supply Paper 616, $194 \mathrm{p}$.

Stearns, H.T., and Macdonald, G.A., 1946, Geology and ground-water resources of the island of Hawaii: Hawaii Division of Hydrography Bulletin 9, 363 p. 


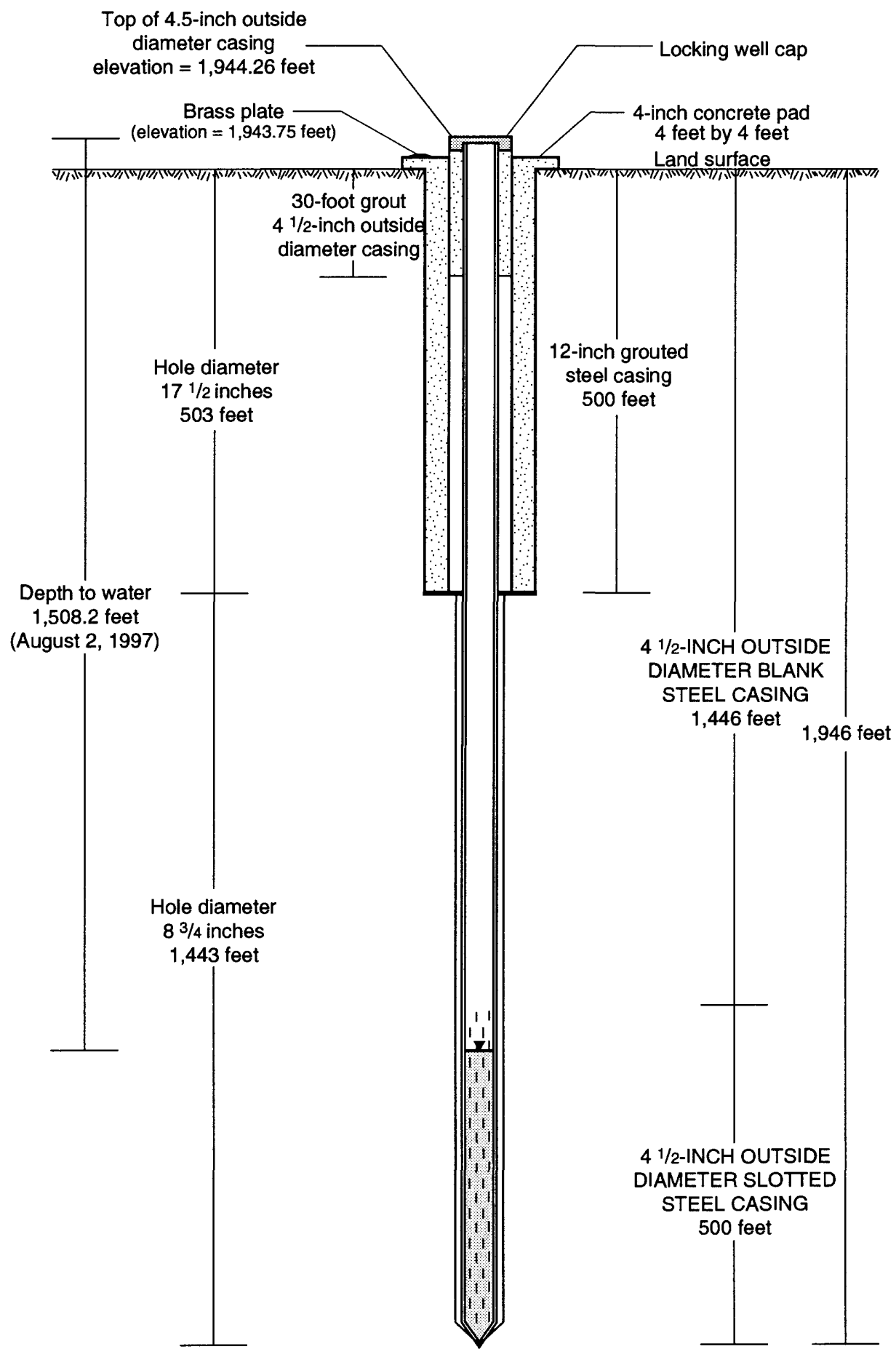

Not to scale

Figure 5. Construction details of the South Point tank exploratory well (State well number 8-0339-01), island of Hawaii. 
Table 3. Driller's log of South Point tank exploratory well (State well number 8-0339-01), island of Hawaii

[Drill crew--G. Wayne Heick, Kimo K. Akina, and Clarence L. Edwards; pilot hole 9-7/8 inches to 500 feet; hole opened to 17-1/2 inches to 500 feet for installation of 12 -inch casing; hole drilled 8-3/4 inches from 500 feet to $1,946 \mathrm{feet} ;{ }^{\circ} \mathrm{C}$, degrees Celsius; $\mu \mathrm{S} / \mathrm{cm}$, microsiemens per centimeter at $25^{\circ} \mathrm{C}$ ]

\begin{tabular}{|c|c|c|c|}
\hline $\begin{array}{l}\text { Depth } \\
\text { (feet) }\end{array}$ & Log/remarks & $\begin{array}{l}\text { Depth } \\
\text { (feet) }\end{array}$ & Log/remarks \\
\hline $0-6$ & Clay, fill, brown, dry & $463-493$ & Blue rock, very hard, no return \\
\hline $6-8$ & Blue rock, very hard & $493-499$ & Blue rock, med-hard, broken, no return \\
\hline $8-30$ & Blue rock, hard & $499-503$ & Blue rock, very hard, casing depth \\
\hline $30-32$ & Blue rock to clinkers & & \\
\hline $32-36$ & Blue rock, hard & & Open hole to $17-1 / 2$ inch, circulation regained \\
\hline $36-41$ & Blue rock with olivine to red broken & & Install $500 \mathrm{ft}$ of 12 -inch steel casing \\
\hline $41-44$ & Blue rock, very hard & & \\
\hline $44-67$ & Red aa, with some grey, medium hard & $503-509$ & Void, lava tube, clinkery, no return \\
\hline $67-70$ & Lava tube, void, lost circulation & $509-519$ & Blue rock, medium to hard, good returns \\
\hline $70-74$ & Blue rock, hard, no return & $519-530$ & Red aa, some blue, medium hard, good returns \\
\hline $74-83$ & Red, clinkery, loose, no return & $530-540$ & Blue rock, medium hard, good return \\
\hline $83-90$ & Red, clinkery, loose, soft, no return & $540-559$ & Red-brown aa, broken, clinkery, medium to soft \\
\hline $90-95$ & Blue rock, hard, no return & $559-562$ & Lava tube, void, clinkers, soft, good returns \\
\hline 95-97 & Red-brown, loose, clinkery, soft & $562-569$ & Red-brown aa, some grey, medium to soft good \\
\hline $97-101$ & Blue rock, hard, no return & & return \\
\hline $101-113$ & Red-brown, loose, medium, no return & $569-571$ & Blue rock, medium hard, good returns \\
\hline $113-128$ & Blue rock, hard, no return & $571-601$ & Brown-grey aa, medium hard, good return \\
\hline $128-136$ & Red-brown aa, medium soft, clinkery & $601-604$ & Blue rock, hard, good return \\
\hline $136-158$ & Blue rock, hard, no return & $604-615$ & Red-brown aa, some grey, soft, clinkery, good \\
\hline $158-161$ & Red-brown aa, soft, no return & & return \\
\hline $161-163$ & Blue rock, hard, no return & $615-630$ & Blue rock, medium to hard, good returns \\
\hline $163-173$ & Cinder/ash??, very soft, no return & $630-634$ & Blue rock, softer, medium hard, good return \\
\hline $173-177$ & Red-brown, clinkery, soft & $634-636$ & Brown-grey aa, medium to soft \\
\hline $177-180$ & Lava tube, void, clinkers, very soft & $636-642$ & Blue rock, hard, good return \\
\hline $180-185$ & Red-brown aa, medium soft, no return & $642-686$ & Blue rock, hard, uniform, good return \\
\hline $185-187$ & Blue rock, very hard, no return & $686-700$ & $\begin{array}{l}\text { Red-brown aa with some grey, medium hard, fair } \\
\text { return }\end{array}$ \\
\hline $187-195$ & Red-brown aa, soft no return & $700-724$ & Red-brown aa, clinkery, broken, soft, fair return \\
\hline $195-198$ & Blue rock, very hard, no return & $724-730$ & Blue rock, hard, uniform, fair return \\
\hline $198-203$ & Red-brown aa, medium to soft, no return & $730-784$ & Red-brown aa with some grey, soft, broken, good \\
\hline $205-205$ & $\begin{array}{l}\text { Red-brown aa, some blue rock, medium hard } \\
\text { Blue rock, hard, no return }\end{array}$ & $784-787$ & $\begin{array}{l}\text { return } \\
\text { Red-brown aa, medium to soft, good return }\end{array}$ \\
\hline $223-241$ & Red-brown aa, medium to soft, no return & $787-810$ & Blue rock, hard, solid, good return \\
\hline $241-245$ & Blue rock, medium hard, no return & $810-827$ & Red-brown aa, medium to soft, good return \\
\hline $245-267$ & Red-brown aa, medium to soft, loose & $827-831$ & Blue rock, medium to hard, good return \\
\hline $267-285$ & Blue rock, hard, no return & $831-863$ & Red-brown-grey aa, soft, clinkery, good return \\
\hline $285-295$ & Red-brown aa, medium to soft, no return & $863-885$ & Blue rock, solid, hard, good return \\
\hline $295-305$ & Blue rock, hard, no return & $885-924$ & Red-brown-yellow, medium hard, good return \\
\hline $305-312$ & Red-brown aa, medium to soft, no return & $924-933$ & Red-brown aa, clinkery, broken, soft \\
\hline $312-318$ & Blue rock, very hard, no return & $933-960$ & Blue rock, medium hard, good return \\
\hline $318-332$ & Blue rock, fractured, no return & $960-978$ & Red-brown aa, soft, loose, clinkery, good return \\
\hline $332-340$ & Red-brown aa, loose, broken, no return & $978-982$ & Void, lost circulation \\
\hline $340-344$ & Blue rock, very hard, no return & $982-984$ & Red-brown aa, some grey, soft, no return \\
\hline $344-367$ & Red-brown aa, broken, loose, no return & $984-986$ & Red-brown aa, some grey, blue, med, no return \\
\hline $367-370$ & Ash/cinder??, very soft & $986-1,006$ & Blue rock, hard, no return \\
\hline $370-372$ & Red-brown aa, clinkery, loose, no return & $1,006-1,035$ & Red-brown aa some grey, clinkery, good return \\
\hline $372-383$ & Blue rock, very hard, no return & $1,035-1,040$ & Blue rock, hard, good return \\
\hline $383-424$ & Blue rock, very hard, no return & $1,040-1,081$ & Red-brown-grey aa, soft, good return \\
\hline $424-440$ & Red-brown aa, some blue, broken, no return & $1,081-1,087$ & Blue rock, hard, some fractures, good return \\
\hline $440-443$ & Blue rock, very hard, no return & $1,087-1,113$ & Grey-brown aa, medium to soft, good return \\
\hline $443-450$ & Blue rock, very hard, no return & $1,113-1,127$ & Blue rock, medium to hard, good return \\
\hline $450-463$ & Blue rock, medium hard, fractured, no return & $1,127-1,144$ & Red-brown-grey aa, broken clinkery, good return \\
\hline
\end{tabular}


Table 3. Driller's log of South Point tank exploratory well (State well number 8-0339-01), island of Hawaii--Continued [Drill crew--G. Wayne Heick, Kimo K. Akina, and Clarence L. Edwards; pilot hole 9-7/8 inches to 500 feet; hole opened to 17-1/2 inches to 500 feet for installation of 12-inch casing; hole drilled 8-3/4 inches from 500 feet to 1,946 feet; ${ }^{\circ} \mathrm{C}$, degrees Celsius; $\mu \mathrm{S} / \mathrm{cm}$, microsiemens per centimeter at $25^{\circ} \mathrm{C}$ ]

\begin{tabular}{cl}
\hline $\begin{array}{c}\text { Depth } \\
\text { (feet) }\end{array}$ & \multicolumn{1}{c}{ Log/remarks } \\
\hline $1,144-1,170$ & Red-brown-grey aa, soft, good return \\
$1,170-1,185$ & $\begin{array}{l}\text { Blue rock grading to red-brown, medium good } \\
\text { return }\end{array}$ \\
$1,185-1,221$ & Blue rock, medium to soft, good return \\
$1,221-1,244$ & Red-brown, soft, good return \\
$1,244-1,250$ & $\begin{array}{l}\text { Red-brown-grey to blue, medium to soft, good } \\
\text { return }\end{array}$ \\
$1,250-1,260$ & Blue rock, very hard, uniform, good return \\
$1,260-1,272$ & Red-brown-grey, soft, broken, clinkery, good \\
& return \\
$1,272-1,289$ & Blue rock, medium to hard, good return \\
$1,289-1,346$ & Blue rock, very hard, solid, good return \\
$1,346-1,391$ & Blue rock, very hard, some olivine, good return \\
$1,391-1,440$ & Blue rock, medium hard, good return \\
$1,440-1,446$ & Blue rock, very hard, good return \\
$1,446-1,500$ & Blue rock, very hard, good return \\
$1,500-1,543$ & Red-brown-grey aa, medium to soft, good return \\
$1,543-1,546$ & Blue rock, very hard, good return \\
& Strip out, check for water in hole, none \\
$1,546-1,552$ & Blue rock, very hard, solid, good return \\
$1,552-1,610$ & $\begin{array}{l}\text { Red-brown-grey aa, soft, broken, clinkery, good } \\
\text { return }\end{array}$ \\
$1,610-1,620$ & Blue rock, hard, solid, good return \\
& Red-brown-grey aa, soft, good return \\
1,626 &
\end{tabular}

\begin{tabular}{|c|c|}
\hline $\begin{array}{l}\text { Depth } \\
\text { (feet) }\end{array}$ & Log/remarks \\
\hline $1,626-1,710$ & Red-brown-grey aa, medium to soft, good return \\
\hline $1,710-1,728$ & Blue rock, very hard, fractured, broken \\
\hline $1,728-1,766$ & $\begin{array}{l}\text { Red-brown-grey aa, medium to soft, good return, } \\
\text { pressure increase, water in return, can airlift water } \\
\text { sample at } 1800 \text { hours, specific conductance } 274 \\
\mu \mathrm{S} / \mathrm{cm} \text {, temperature } 24.3^{\circ} \mathrm{C}\end{array}$ \\
\hline 1,766 & $\begin{array}{l}\text { Red-brown-grey aa, medium to soft, good return, } \\
\text { water sample at } 1,766 \mathrm{ft} \text { at } 0800 \text { hours, specific } \\
\text { conductance } 195 \mu \mathrm{S} / \mathrm{cm} \text {, temperature } 23.9^{\circ} \mathrm{C}\end{array}$ \\
\hline $1,770-1,786$ & Blue rock, very hard, good return \\
\hline $1,786-1,800$ & Red-brown-grey aa, medium to soft, lots of water \\
\hline $1,800-1,826$ & Blue rock, very hard, good return \\
\hline $1,826-1,846$ & Blue rock, very hard, good return, plenty of water \\
\hline $1,846-1,850$ & Blue rock, very hard, good return \\
\hline $1,850-1,865$ & Red, brown-grey aa, medium to soft, good return \\
\hline $1,865-1,890$ & Blue rock, very hard, some fractures, good return \\
\hline $1,890-1,940$ & Blue rock, very hard, solid, good return \\
\hline \multirow[t]{3}{*}{$1,940-1,946$} & $\begin{array}{l}\text { Blue rock, medium, good returns, drilling com- } \\
\text { plete }\end{array}$ \\
\hline & $\begin{array}{l}\text { Depth to water is } 1,509.2 \mathrm{ft} \text { at } 1200 \text { hours July } 20 \text {, } \\
1997\end{array}$ \\
\hline & Install 4-inch casing ${ }^{1}$ \\
\hline
\end{tabular}

1 Additional water-level measurements made after 1200 hours on July 20, 1997 are listed in table 5 
Table 4. Water-quality measurements for South Point tank exploratory well for water samples obtained by airlift while drilling ${ }^{1}$ [Drill crew--G. Wayne Heick, Kimo K. Akina, and Clarence L. Edwards; pilot hole 9-7/8 inches to 500 feet; hole opened to 17-1/2 inches to 500 feet for installation of 12-inch casing; hole drilled 8-3/4 inches from 500 feet to 1,946 feet; $\mu \mathrm{S} / \mathrm{cm}$, microsiemens per centimeter; ${ }^{\circ} \mathrm{C}$, degrees Celsius; mg/L, milligrams per liter]

\begin{tabular}{ccccc}
\hline Date & Time & $\begin{array}{c}\text { Depth } \\
(\mathrm{feet})\end{array}$ & $\begin{array}{c}\text { Specific conductance } \\
(\mu \mathrm{S} / \mathrm{cm})\end{array}$ & $\begin{array}{c}\text { Temperature } \\
\left({ }^{\circ} \mathrm{C}\right)\end{array}$ \\
\hline $7 / 16 / 97$ & 1730 & 1,726 & 274 & 24.3 \\
$7 / 17 / 97$ & 0830 & 1,766 & 195 & 23.9 \\
$7 / 17 / 97$ & 1530 & 1,826 & 165 & 24.2 \\
$7 / 19 / 97$ & 1115 & 1,826 & 230 & 23.2 \\
$7 / 31 / 97$ & 1340 & 1,826 & 294 & 23.1 \\
$7 / 31 / 97$ & 1650 & 1,846 & 180 & 21.4 \\
$8 / 1 / 97$ & 0830 & 1,846 & 161 & 22.0 \\
$8 / 1 / 97$ & 1445 & 1,946 & 131 & 22.6 \\
\hline
\end{tabular}

1 Conductance and temperature values are altered by drilling fluids and compressed air. Most representative conductance was obtained on August 1, 1997 at 1445 hours after several hours of air lift pumping without drilling fluids

Table 5. Depths to water during drilling at South Point tank exploratory well (State well number 8-0339-01), island of Hawaii [Ground surface elevation: 1,944 feet above mean sea level]

\begin{tabular}{cccc}
\hline Date & Time & $\begin{array}{c}\text { Depth to water } \\
\text { feet below } \\
\text { top of casing) }\end{array}$ & $\begin{array}{c}\text { Water level } \\
\text { (feet above } \\
\text { mean sea level) }\end{array}$ \\
\hline $7 / 20 / 97$ & 1200 & $1,509.2$ & 435.1 \\
$7 / 20 / 97$ & 1700 & $1,508.5$ & 435.8 \\
$7 / 21 / 97$ & 0800 & $1,508.4$ & 435.9 \\
$7 / 21 / 97$ & 1700 & $1,508.4$ & 435.9 \\
$7 / 22 / 97$ & 0730 & $1,508.4$ & 435.9 \\
$7 / 22 / 97$ & 1730 & $1,508.5$ & 435.8 \\
$7 / 23 / 97$ & 0730 & $1,508.4$ & 435.9 \\
$7 / 30 / 97$ & 1700 & $1,508.4$ & 435.9 \\
$7 / 31 / 97$ & 0730 & $1,508.5$ & 435.8 \\
$8 / 2 / 97$ & 1100 & $1,507.5$ & 436.8 \\
$8 / 2 / 97$ & 1730 & $1,508.2$ & 436.1 \\
\hline
\end{tabular}

